\title{
Comparative Study of Photochemical and Proximate Analysis of Breadfruit Seeds, Leaves and Barks
}

\author{
Ajetunmobi Asibiallau Oladipupo \\ Department of Science Laboratory Technology (Chemistry Unit), School of Technology, Lagos State \\ Polytechnic, Ikorodu, Lagos, Nigeria
}

\begin{abstract}
A study was conducted to determine the phytochemical and proximate analysis breadfruit leaves, seeds and barks

Fresh leaves, seed and bark were collected and dried under room temperature for sixty days. The dried leaves, seed and the bark of the tree were grounded separately and put in different sterile bottle.

It was found that the leaves, seed and bark of breadfruit contain some phytochemicals like essential oil, saponin, phenolic compound, sugar, flavours alkaloids and tannin except Amino acid that was absent. The result of the proximate analysis showed that the seed had higher content in terms of percentages in all parameters than the leaves and barks.
\end{abstract}

Key words: Phytochemical, proximate analysis, Artocarpusalitis

\section{Introduction}

The breadfruit Artocarpusaltilis belong to the malbery family moraceana. The tree is handsome and fast growing reaching up to $85 \mathrm{ft}$ between 2 to $6 \mathrm{ft}$ in width. (Maton. 1987). Breadfruit is scientifically known as ArtocarpusAltilis

Breadfruit has been since the $12^{\text {th }}$ Century A.D and believed to have been widely spread in the pacific area by migrating Polynesians and Hawaiians brought from the Samon Island of Upalu to Ohau. It was first seen by the Europeans in the marquesan in 1595. Then in Tahiti in 1606. It gained its fame in the $18^{\text {th }}$ century with the English Explorers and during the period of famine in Jamaica between 1786 and 1788. It produces its fruit up to 2-3 times in a year and the number of fruit is rich in latex and can weight 1-4kg. (Richburg T.I.et al)

The leaves of breadfruit are evergreen or deciduous, depending on the climatic condition, on thick yellow petioles. They are ovate about 9.36 inches long and 8.20 inches wide entire at the base. They are bright green glossy on the upper surface with conspicuous yellow vein, dull yellowish and coated with minute stiff hair on the underside (Morton, 1987).

The seed are irregular oval, minded at end, pointed at the other about $2 \mathrm{~cm}$ long, dull brown and darker stripes. In the green stage, the fruit is handsome and the interior is white starchy and somewhat fibrous.

When fully ripe, the fruit is somewhat soft the interior is cream coloured or yellow and pasty, with sweet fragrant (John, 2009)

Breadfruit is a fruit tree that is propagated with root cutting and the average age of bearing fruit is between 4-6 years. It produces its fruit up to 2-3 times a years, and number of fruit produced is very high.

The plant occurs in the wild in Iran and Micronesia, while its secondary centre of diversity is Polynesia. It is commonly cultural in several other tropical countries like west Indies, Ghana, Sierra Leone, Nigeria and Jamaica, Breadfruit has been described as an important staple food of high economic value. It is a source of carbohydrate and forms a portion of the diet in several countries particularly in the highland of the south pacific. (Morton, 187)

It was also used as food for slaves in British West Indies during the reign of King George III. The United State Department of Agriculture brought in breadfruit plants from the canal zone, Panama in 1906. (Morton, 1987.

The breadfruit pulps are made into various dishes, it can be pounded, fried boiled or mashed to made porridge. It can also ground into flour and used in bread and biscuit making. Due to its high amount of carbohydrate, it can easily replace such carbohydrate-rich fruit like banana. Carbohydrates are thought to be higher. Breadfruit is also known to be rich in fat, ash, fibre and protein. (Amusa, 2002).

Despite the important of breadfruit, its production is faced with several problems. This includes short shelf life and poor yield due to diseases. Since the shelf lives of breadfruit are short, they are often utilized in Nigeria within 5 days of harvesting. However, it can take up to 10 days after harvesting to get to markets in some major cities, resulting in large loss due to bio-deterioration (Amusaetal. 2002)

This study is designed to investigate phytochemical and proximate analysis of breadfruit leave, seed and bark extracts due to the economic importance of the tree.Breadfruit is a large round seedless or seeded fruit with a texture like bread eaten boiled, baked or roasted. The tree yields other products of economic value such 
as native cloth from the fibrous inner plant of young trees. The wood is used for canoes and articles of furniture and a kid of glue materials are obtained from the viscid milky juice, which extrude from incision mass in the stem.

In the Pacific Islands, the fruit is preserved for use by storing in pits where the fruit ferments and resolves them into a mass similar in consistency to new cheese, in which they emit an offensive odour. After baking under hot stones, they yield a pleasant and nutritious food.(Motina. M.R et.al)

One of the main pest of breadfruit as found in the west Indies are ant and mealy bugs. Diseases that affect breadfruit include soft rot in southern India, die back cause by Fusariumspp in the Pacific Island, root rot caused by Pythiumspp and other kinds of disease by Rosellinaspp, PhytophoraPalmivora attacks the fruit on the Island of truck while Phomopsis, Dothwrell and Phylosira cause stem rot (Morton 1987).

Breadfruit leaves is used to lower blood pressure and to relieve asthma.

Crushed leaves are applied on the tongue for treating thrush

The leaf juice is also employed as ear-drop and the ashes of burnt leaves is used on skin infections.

A powder of roasted leaves is employed as a remedy for enlarged spleen.

Toasted flowers are used to treat aching too by rubbing it on the gums. The latex is used to treat diarrhea. (Morton, 1987).

Most varieties of breadfruit are purgative if eaten raw. Some varieties are boiled twice and the water thrown away to avoid unpleasant effects, while there are a few named cultivers that can be safely eaten without cooking.

The cyclopropane sterol cycle-astenol, has been isolated from the flesh fruit.

It constitutes $12 \%$ of the non-saponifiable extract.

\section{Materials And Methods}

Fresh leaves, seeds and barks of the breadfruit (Artocarpusartilis) were dried, blended with mortar and pestle to powdered form and kept under room temperature for sixty days in sterile bottles for further analysis. Qualitative phytochemical evaluation was carried out to test the presence of alkaloids, flavones, sugar, phenolic group, saponin, amino acid and essential oil in the extracts samples using modified method of Brindha et al. (1981)

Tannin: A test solution was made with distilled water to which $0.01 \mathrm{~g}$ lead acetate was added. The development of a white turbidity in the precipitate represented the presence of tannin.

Alkaloids: A test solution was made with 2N HCI. The aqueous layer was decanted. To the lower layer 2 drops of Mayer's reagent was added. Development of a white turbidity in the precipitate represented the presence of alkaloids.

Flavones: The test solution was mixed with $100 \mu 1$ of alcohol, $0.02 \mathrm{~g}$ of paradimethy 1 amine benzaldehyde and two drops of conc. HCl. Development of red or pink colour indicate the presence of flavones

Sugar: The test solution was made in a clean test tube, to which $0.01 \mathrm{~g}$ of anthrone and 3 drops of conc. $\mathrm{H}_{2} \mathrm{SO}_{4}$ were added. The solution was heated for 1 to 2 minutes. Change of green to purple colour was noted to detect the presence of sugar in the sample.

Phenoplic group: An alcoholic plant extract was prepared in a test tube. Two drops of $1 \mathrm{M}$ ferric chloride were added. Appearance of intense color indicated the presence of phenolic groups.

Saponin: A test solution with distilled water ( 2 drops) was prepared in a test tube. The development of a foamy lather indicated the presence of saponin.

Amino acid: A test solution made with two drops of $1 \%$ ninhydrine in alcohol was prepared in a test tube. Blue or violet colour development indicated the presence of amino acid.

Essential oil: A test solution made with two drops of $1 \mathrm{M}$ alcoholic $\mathrm{K}_{2} \mathrm{Cr}_{2} \mathrm{O}_{7}$ and 3 drops of phenotheline was prepared in a clean test tube. Soap formation indicated the presence of essential oil.

\section{Proximate Analysis}

The proximate analysis of breadfruit seeds leaves and barks samples were determined using standard methods $(3,23,24)$. The samples analysed for crude fibre, moisture, crude protein, ash, fat and carbohydrate.

\section{Results}

\section{Proximate analysis of sample A (seed)}

\begin{tabular}{|l|l|l|l|l|l|}
\hline Parameter & I & II & III & IV & Mean Value \\
\hline Crude fibre \% & 13.08 & 12.30 & 13.0 & 13.10 & 12.87 \\
\hline Fat \% & 6.0 & 5.8 & 3.5 & 4.5 & 4.95 \\
\hline Moisture \% & 55.10 & 35.20 & 55.10 & 80 & 55.0 \\
\hline Carbohydrate & 80 & 82 & 55.20 & 80.5 & 80.62 \\
\hline Crude protein \% & 26.88 & 26.80 & 26.60 & 26.59 & 26.72 \\
\hline Ash \% & 6.8 & 6.75 & 6.90 & 6.85 & 6.83 \\
\hline
\end{tabular}


Proximate analysis of sample B (Leave)

\begin{tabular}{|l|l|l|l|l|l|}
\hline Parameter & I & II & III & IV & Mean Value \\
\hline Crude fibre \% & 10.63 & 10.58 & 10.60 & 10.65 & 10.64 \\
\hline Fat \% & 3.60 & 3.66 & 3.59 & 3.60 & 3.61 \\
\hline Moisture \% & 25.70 & 25.40 & 25.60 & 25.60 & 25.50 \\
\hline Carbohydrate & 50.15 & 50.10 & 50.15 & 50.10 & 50.0 \\
\hline Crude protein \% & 22.60 & 22.40 & 22.50 & 22.30 & 22.45 \\
\hline Ash \% & 10.50 & 10.60 & 10.65 & 10.59 & 10.59 \\
\hline
\end{tabular}

Proximate analysis sample C (Bark)

\begin{tabular}{|l|l|l|l|l|l|}
\hline Parameter & I & II & III & IV & Mean Value \\
\hline Crude fibre \% & 10.50 & 10.56 & 10.48 & 11.0 & 10.64 \\
\hline Fat \% & 3.60 & 3.65 & 3.60 & 3.63 & 3.62 \\
\hline Moisture \% & 12.20 & 12.10 & 12.0 & 12.0 & 12.01 \\
\hline Carbohydrate & 22.60 & 22.40 & 22.60 & 22.40 & 22.50 \\
\hline Crude protein \% & 12.85 & 12.80 & 12.81 & 12.83 & 12.82 \\
\hline Ash \% & 18.80 & 18.75 & 18.80 & 18.82 & 18.80 \\
\hline
\end{tabular}

Phytochemical analysis

\begin{tabular}{|l|l|l|l|}
\hline Parameter & A & B & C \\
\hline Essential oil & $\underline{\text { III }}$ & $\underline{\text { II }}$ & $\underline{\text { II }}$ \\
\hline Saponin & $\underline{\text { III }}$ & $\underline{\text { III }}$ & $\underline{\text { III }}$ \\
\hline Phenolic & $\underline{\text { III }}$ & $\underline{\text { II }}$ & $\underline{\text { II }}$ \\
\hline Amino acid & - & - & - \\
\hline Tanrnin & $\underline{\text { III }}$ & $\underline{\text { II }}$ & $\underline{\text { II }}$ \\
\hline Alkaloida & $\underline{\text { III }}$ & $\underline{\text { II }}$ & $\underline{\text { II }}$ \\
\hline Flavones & $\underline{\text { II }}$ & $\underline{\text { II }}$ & $\underline{\text { II }}$ \\
\hline
\end{tabular}

IV. Discussion

The bread fruit seeds have higher value in terms of proximate analysis than the leaves and barks. The protein content is important and responsible for the elasticity of and dough formation during bread making. Crude fibre has been known to promote health as it aids the digestive system of human, eating breadfruit equally aids in digestion of foods. The fat contents plays vital role in the determination of shelf life of foods. Too high amount of fat is very undesirable and cause spoilage leading to off flavours and odorous development.

The ash contents helps in enhancing the mineral intake of people. It should be noted that ash content is indicative of the amount of mineral contained in food sample.

Moisture is very important factors in the keeping quality of food, high moisture content have an adverse effect on storage stability.

\section{Conclusion}

Intake of bread fruit or when mixed with other foods have a good medicinal effect on human.

\section{References}

[1]. AACC (1983):- Approved methods of AACC method 30-258 $8^{\text {th }}$ edition Aner. Association cereal chemistry st.davil, MN

[2]. Aguilera JM. And Lusas E.M (1986) laboratory and pilot extraction of extruded of high oil corn J. Aner oil them. Sod 63:239-243)

[3]. AOAC (1995) official analysis $\left(15^{\text {th }}\right.$ Ed Association of Official of Analytical Chemists ariahu. C.C. Ukpabi U. and Mbajunwa K.O (1999)

[4]. Beintez. I.V (1989) amino acids of fatty acids of profiles in agriculture nutrition study in fish nutrition research in asia, proceeding of third Asian fish SS. Die silva (ed) soc. Spec. published 4: 166p Asian. Fishes. Society

[5]. Camovale E. cappeloni M. moseoni C. Marietta I. and pollinis C (1987) Effect of extrusion cooking on protein availability and sulphur amino acids of faba bean and chilpea products proceeding of the $7^{\text {th }}$ world congress food. Science Technology.Trends in food processing I membrane.Filtration technology and theimal processing and quality of food.Singapore October. A4. Ghee et al (tds) 241-246)

[6]. Dashivil K.E. singh. S.R. Nakayama, O ogundipe H.O and Akeem C.N. (1990) clip a research, Monograph, No 2 soyabean research at HTA Ibadan an Nigeria FAO/WHO (3973 Energy and protein requirement report of joint FAO/WHO adHoc Expert comm. Ctt.Rome.

[7]. GUJSKA. E and Khan.K (199)) effect from high starch fraction of navy pointo and gralbanzo.Beans.J Food.Sci 55:466-469

[8]. IweO.VanZuilichem. Dj. Ngoddy F.O and Lammers, W (2001) amino acid and protein dipersibility index. (F DIS of mixture of exl.rikted.Soy and svyeei potato. Flours.Lebensmitd - wissseis.Chift und-technologies 34:71-75

[9]. Lesekan O.O and Akintola A.M 2002 production and nutritional evaluation of puffed soy maize snack nig.Fodd J. 20:15-19

[10]. Maga J.A and Lrenz, K. (1978) sensoyblend.Slebensmitted.Wisgensehaftundtehnologies 111.2185)

[11]. Molina M.R Braham J.E and Brssani R (1983) some characteristic of whole corn whole soybean (70:30) and rice while soybean (70:30 mixtures processed by simple extrusion cooking J. FOOD.SCIi. 48.434-437. 
[12]. Nwabueze T.U and iwe M.O (2006) mass flow. Safe nutrient composition and some function properties of single extruded African breadfruit (treculia-African) blends. Journal of good technology 4(1):50-58

[13]. O.I server Applied Science London and New York pp. 332-340sindeeor G.W and Cochran. W (1980) statistical methods (7thedn/owa. State University Presames. IA. Pg 215)

[14]. Production of African breadfruit (Treculia-African and soybean (glucine max) seed food formulation I seed based food formulation on nutritional and organoleptic qualify plant food hum nutritional 54:193-206

[15]. RDA (1989) Recommended dietary allowance $10^{\text {th }}$. Ed. National Research Council National Academy Press.

[16]. Richburg T.I and Whittaker A.D of a twin-screw - extruderin engineering and food advanced processes. Spies. W.EL and Schubert, it eds

[17]. Sotillo.E and hettiarachehy, N.S (1994).Corn.Meal. Sun flower meal. Extrudates and their physicochemical properties.J.Food Science 59:Pg 432-435

[18]. Spackman D.H. Stein. Eh and Moore, S. (195 8) Automatic recording apparatus for use in the chromatography of amino acids analytical chemical. 30:11-1191

[19]. Umoh. I B and Bassir O. (1977) Lesser known sources of protein in some Nigerian-peasant diet. Food chemistry 2:315

[20]. We. M.O.Van.zuilichem. D.J. stolp.W. and Ngoddy.P.O. (2004) effect of extrusion cooking of soy potato mixtures on 1.Available lysine.Conten.And browing.Index.Of extrudates. J. food enger

[21]. Amusa N.A, Kehinde I.A and O.A Ashaye Bio-deterioration of breadfruit in storage and its effect on the nutrient composition 2002

[22]. Esuoso K.O and F.O Bamiro studies on the baking properties of non-wheat flour breadfruit, Int. Journal of food science nutrition

[23]. Asiedu J.J. processing Tropical Crops, Mcmillan Education Ltd, London $1^{\text {st }}$ edition 1989

[24]. Egan H, Kirk RS and R Sawyer Pearson's chemical analysis of foods $8^{\text {th }}$ edition Churchill livingstone, medical division of long group Ltd. Great-Britain

[25]. Morton JF and FL Miami Breadfruit, In: fruits of warm climates 1987 